\title{
Attitudes toward newcomers from the city. The case of urban-rural fringe of Krakow
}

\begin{abstract}
Rural-urban areas are currently characterised by a high rate of economic development. One of the results of these changes is the inflow of urban populations, who are very different from the indigenous inhabitants. In spite of the move to a rural environment, they often preserve their customs and urban life styles; while, on the other hand, the indigenous inhabitants of rural areas tend to present traditional attitudes towards life. They are strongly attached to their land and identify with their place of residence. The author focuses on the attitudes expressed toward newcomers from Krakow and other metropolitan cities by the inhabitants of selected municipalities within the Krakow Metropolitan Area (KOM). The attitudes toward styles, ways of life, values, as well as preferences brought by the urban population were investigated.
\end{abstract}

Keywords

Attitudes toward newcomers $\cdot$ rural areas $•$ Krakow Metropolitan Area

(C) University of Warsaw - Faculty of Geography and Regional Studies
Halina Pawlak

Institute of Geography and Spatial Management,

Faculty of Geography and Geology,

Jagiellonian University in Kraków, Poland

e-mail: halina.pawlak@uj.edu.pl

\section{Introduction}

The rural areas of Poland vary greatly, both spatially and functionally. Socio-economic changes that have taken place during the last 25 years, inter alia, a return to the free market economy, the establishment of local governments at a municipal level, and the EU accession, have contributed substantially to the transformation of rural areas. However, the fastest pace for rural area development is observed in the immediate vicinity of large cities. It is vital to determine how wide the cities' range of influence is and to what extent the city changes the functions of rural areas with regards to settlement, social, and economic aspects. Rural areas located in the vicinity of a big city are characterised by a large variety of features and interpenetrating functions. Moreover, the city affects the progressive and multifunctional development of the urban-rural fringe. The decreasing role of agriculture - or even its total disappearance - is being observed: replaced by housing, services, production, and recreational functions. On the other hand, an increase in population as a result of urban population inflow has been recorded; while in addition, the population's level of education is rising. The number of people employed in agriculture is decreasing, whereas employment in services is expanding. Furthermore, the migrants from urban areas bring with them their habits and urban lifestyle, while the rural population often represents traditional beliefs and life attitudes, has a strong attachment to the land, and a sense of identity with the place in which they live. Encountering such different ways of living, behaviours, cultures, as well as the expectations of the indigenous inhabitants and newcomers may raise many concerns or even contribute to some conflicts.

The problem of social relations between urban migrants and indigenous suburban inhabitants has been described by authors from many Central and Eastern European countries: Hirt (2007), Novák and Sýkora (2007), Mantey (2011) Špačková and Ourednícek (2012). The authors of these articles have pointed to a lack of a bond between urban and indigenous inhabitants, land ownership conflicts, and the spatial and social isolation of residents.

The purpose of this paper is to present the diversity in attitudes of Krakow's urban-rural fringe inhabitants toward newcomers from the city.

\section{Human attitude concept}

The term attitude was introduced by W. J. Thomas and F. Znaniecki (1918-1920). It serves to describe the processes of individual consciousness that specify both the actual and potential reactions of each person toward the social world. The structure of attitude involves three components that interweave and supplement each other (Mądrzycki 1977; Mika 1984; Turowski 1996; Leśniak-Moczuk \& Moczuk 2002); they are: the cognitive element (knowledge, beliefs, and presumptions), the emotional and evaluative element (moral, aesthetic, social, religious etc. feelings), and the behavioural element (action, reaction).

It may therefore be assumed that an attitude is a mechanism that regulates human behaviour toward the subject of the attitude. This mechanism results from the individual's opinions, feelings, or aspirations related to the subject of this attitude (ed. Nowak 1973).

\section{Study Area and Sample Characteristics}

The study area covered selected rural municipalities of the Krakow Metropolitan Area (KOM). The coverage of this area was determined on the basis of the delimitation elaborated 


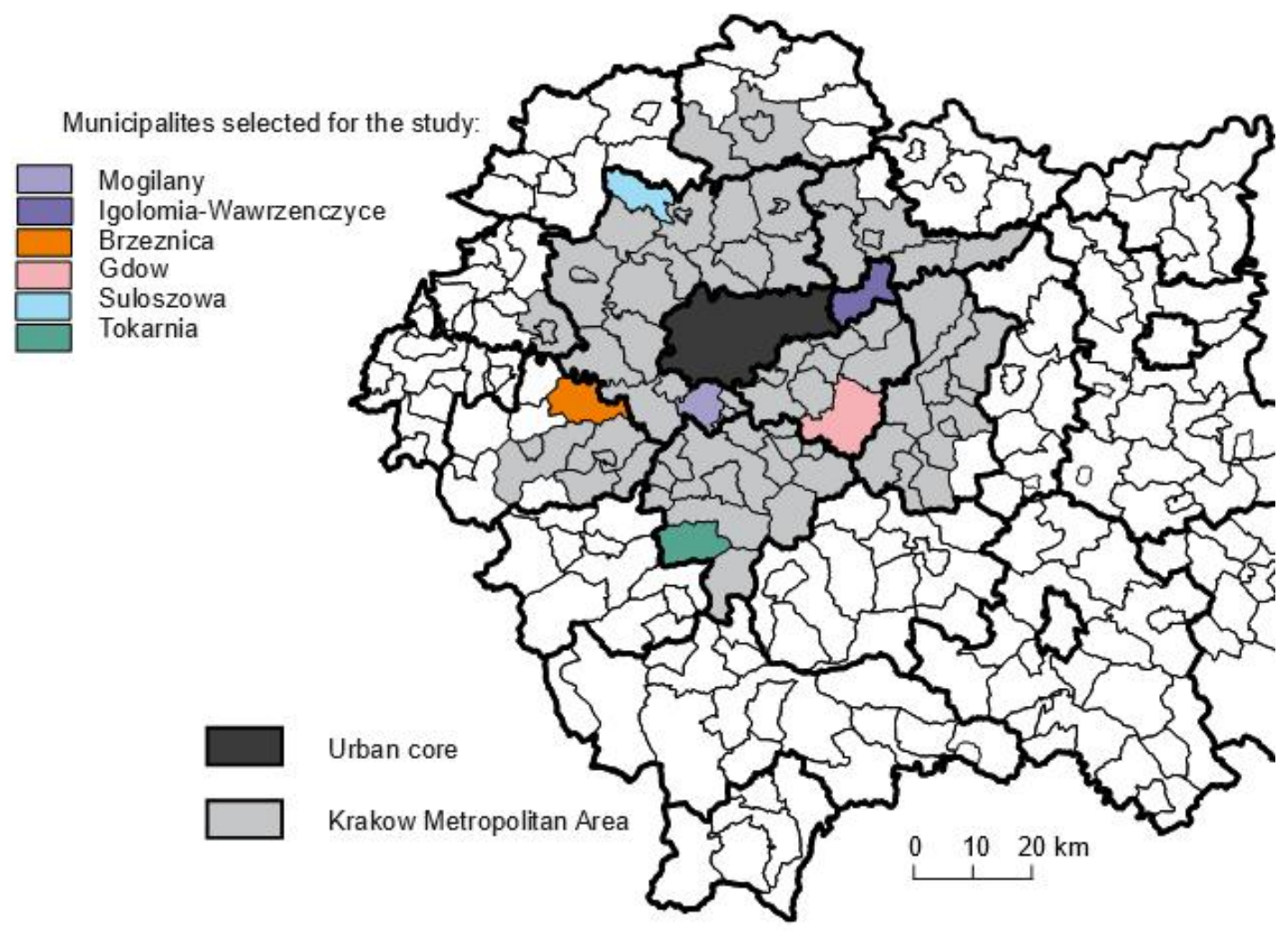

Figure 1. Location of municipalities selected for the study within Malopolskie Voivodeship and the Krakow Metropolitan Area Source: author's work based on Zborowski et al. 2010.

by Zborowski et al. (2010). The following criteria were adopted in order to choose municipalities for the study: the level of the development of urbanization processes, the level of agricultural development, the intensity of commuting, as well as their location in relation to Krakow. Eventually, six municipalities were chosen. These municipalities are located in three different zones, which were given designations based on their administrative location in relation to Krakow. Zone I embraced municipalities bordering the urban core (Igolomia-Wawrzenczyce, Mogilany). Municipalities separated from Krakow by one municipality constituted zone II (Brzeznica, Gdow), whereas zone III contained those municipalities that were separated from the city by at least two administrative units (Suloszowa, Tokarnia). The spatial location of the selected municipalities is presented in Figure 1.

The data used for the study was derived from a research survey carried out during July-September 2012. Questionnaire interviews were conducted with indigenous inhabitants of selected rural municipalities located within the KOM. A total number of 1,230 respondents - inhabitants of the municipalities IgolomiaWawrzenczyce, Mogilany, Brzeznica, Gdow, Suloszowa, and Tokarnia - took part in the study. Women constituted $63.0 \%$ of the sample, whereas $37.0 \%$ were men. Inhabitants who had moved from the city to the investigated municipalities were excluded from the study. More than $68.0 \%$ of respondents had lived in their current place of residence since birth. The rest had moved there from other rural areas, mainly located within the same municipality. The inhabitants' attitudes toward newcomers from Krakow or other metropolitan cities were investigated; in particular, the attitudes toward lifestyles, values, and preferences brought by urban dwellers to rural areas were researched.
Results

Concerns about newcomers from the city

Anxiety to do with changes or novelty is one of the elements that expresses an individual's attitude. Such anxiety can elicit a subjective evaluation of a phenomenon or a person.. Thus, the respondents were asked the question: Are you afraid of newcomers from the city? However, the majority did not express such anxiety; only $5 \%$ of respondents answered "definitely yes." Some fears were expressed by $9.0 \%$ of respondents, whereas almost $46.0 \%$ were rather not afraid, and $32.0 \%$ were definitely not afraid of the newcomers.

The answers did not vary in relation to the distance from Krakow; however, differentiation was observed even among respondents living within one zone. Among the inhabitants of municipalities neighbouring Krakow, respondents from Igolomia-Wawrzenczyce were the least afraid of newcomers $(1.4 \%)$, whereas almost $6 \%$ of respondents from Mogilany municipality expressed anxiety due to new residents. The share of respondents declaring they are definitely afraid of newcomers was $1.5 \%$ in Brzeznica, but $12.0 \%$ in Gdow. At the same time, when compared to the other investigated municipalities, Gdow municipality was characterized by the smallest number of respondents who expressed a firm lack of fear toward immigrants from the city (7\%) (Fig. 2). The answers from the respondents from the most distant municipalities - Suloszowa and Tokarnia were less diverse. In Suloszowa less than $10.0 \%$ of respondents declared concerns about newcomers, whereas in Tokarnia it was $15.0 \%$.

A thorough analysis shows that Gdow, characterised by the highest proportion of respondents who are anxious about 
MISCELLANEA GEOGRAPHICA - REGIONAL STUDIES ON DEVELOPMENT

Vol. $22 \cdot$ No. $1 \cdot 2018 \cdot$ pp. 40-47 • ISSN: 2084-6118 • DOI: 10.2478/mgrsd-2018-0004

Table 1. Share of households earning income from agricultural activities, mean urban to rural areas net migration rate for the years 2002-2012, share of respondents working in agriculture

\begin{tabular}{|c|c|c|c|}
\hline Municipality & $\begin{array}{c}\text { Share of-households earning } \\
\text { income from agricultural } \\
\text { activities in 2010 [\%] }\end{array}$ & $\begin{array}{c}\text { Urban to rural areas mean } \\
\text { net migration rate / 1,000 } \\
\text { inhabitants for the years } \\
\text { 2002-2012* [\%] }\end{array}$ & $\begin{array}{c}\text { Respondents working } \\
\text { in agriculture / working } \\
\text { respondents** [\%] }\end{array}$ \\
\hline Igolomia-Wawrzenczyce & 91.7 & 0.86 & 45.22 \\
\hline Mogilany & 61.1 & 14.64 & 6.67 \\
\hline Brzeznica & 83.8 & 2.82 & 7.61 \\
\hline Gdow & 83.1 & 4.39 & 47.37 \\
\hline Suloszowa & 91.3 & -0.04 & 44.53 \\
\hline Tokarnia & 58.6 & 0.56 & 20.41 \\
\hline
\end{tabular}

Source: *Central Statistical Office, 2012 and 2010; **own research

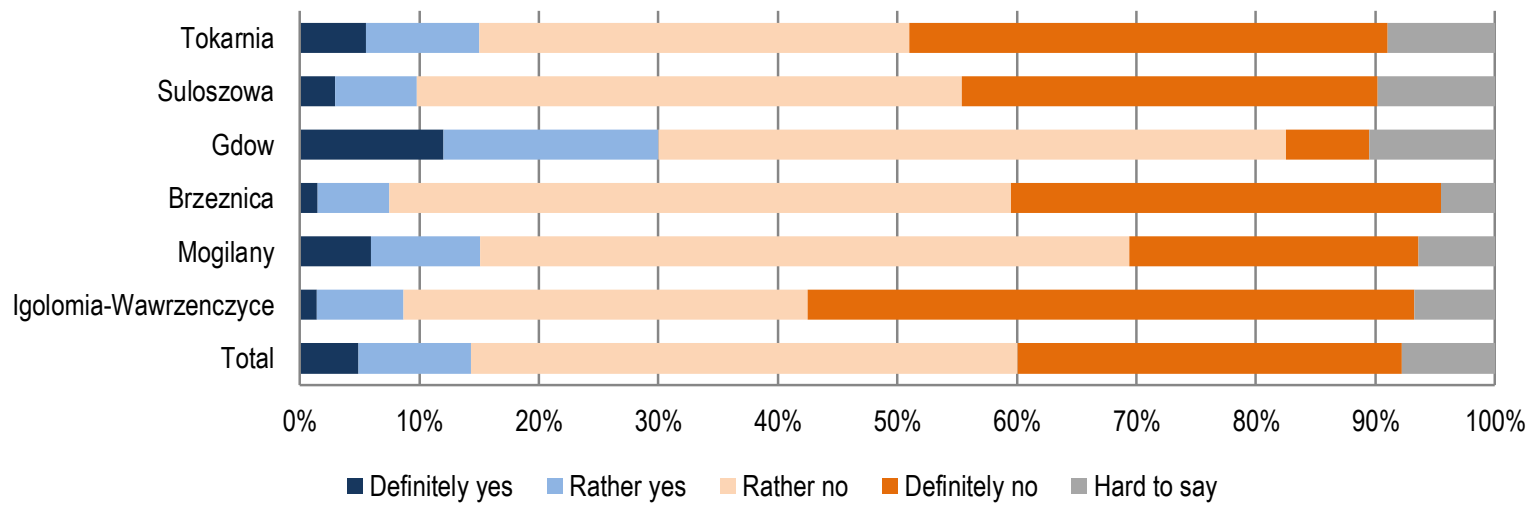

Figure 2. Concerns about newcomers from the city

Source: own research

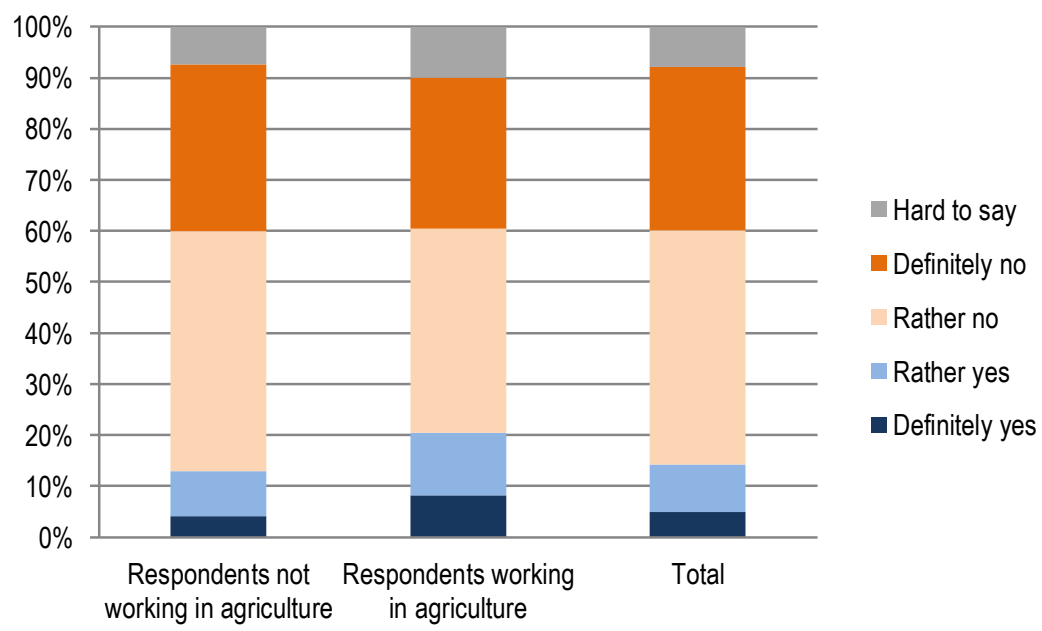

Figure 3. Concerns about newcomers from the city, broken down according to work in agriculture.

Source: own research 


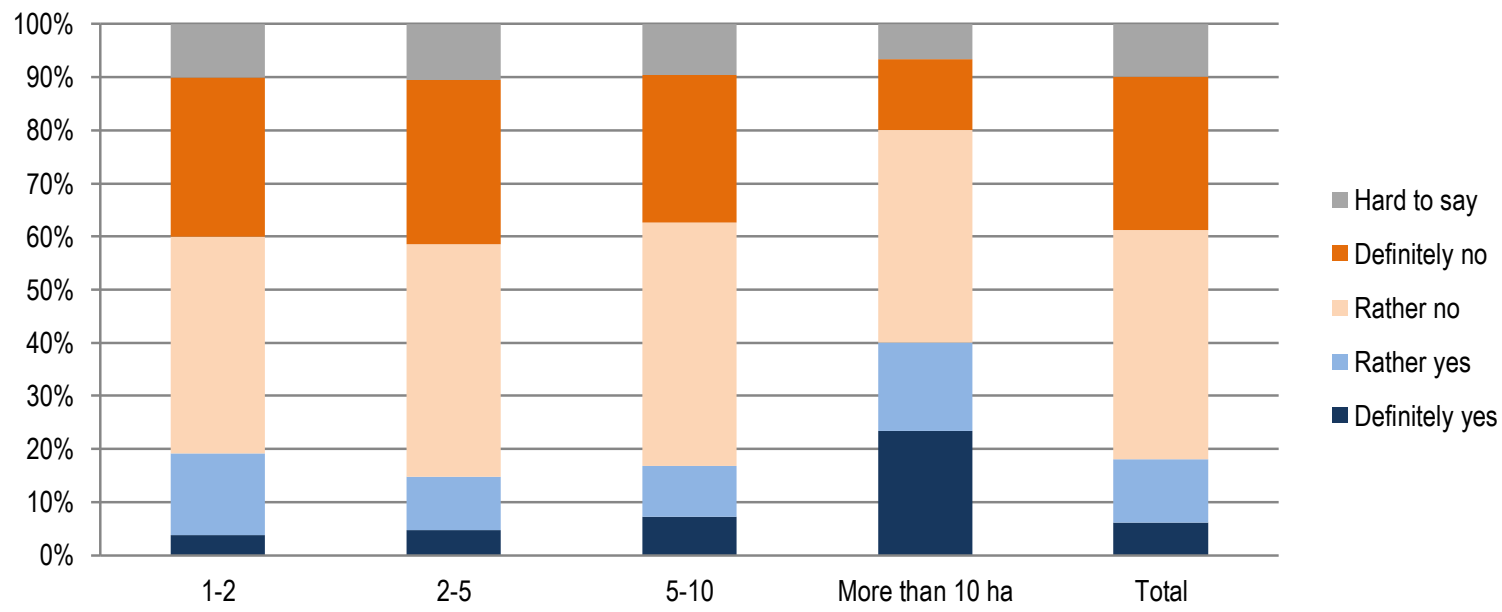

Figure 4. Concerns about newcomers from the city, broken down according to the farm size Source: own research

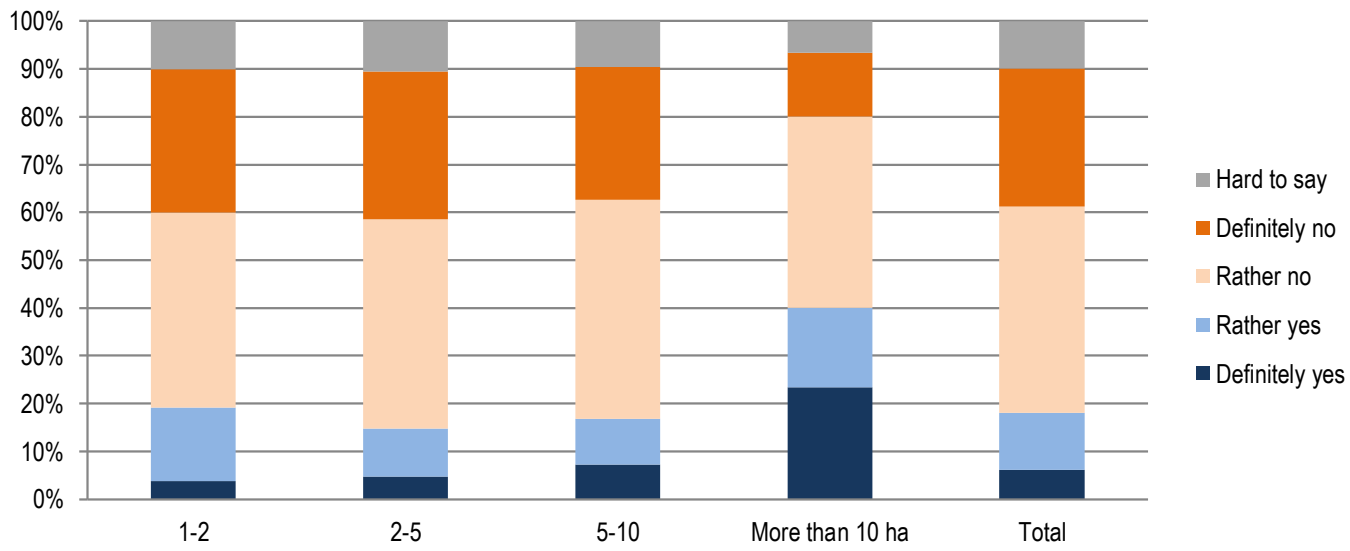

Figure 5. Respondents' sense that new inhabitants consider themselves to be better than others Source: own research

newcomers from the city, is a rural municipality that has been experiencing a significant inflow of urban population within recent years. The share of households with an income from agricultural activities was $83.1 \%$ in 2010 (GUS 2010). Simultaneously, the average net migration rate for the years 2002-2012 reached $4.4 \%$. On the other hand, the other municipalities with significant proportions of households earning income from agricultural activities; namely: Igolomia-Wawrzenczyce (91.7\%) and Suloszowa $(91.3 \%)$, noted very low net migration rates: $0.86 \%$ o and $-0.04 \%$ respectively (Table 1 ).

In three out of the researched municipalities almost half of respondents declared that they worked in agriculture: Gdow, 47\%; Igolomia-Wawrzenczyce, 45\%; and Suloszowa, 44.5\%. Hence, it seems worthwhile to compare the opinions of respondents working and not working in agriculture (Fig. 3).

Respondents who worked in agriculture declared they had concerns about newcomers from the city more often than others. They also constituted the majority within the group of respondents who gave unspecified answer.

Among farm owners, those who had large farms exhibited the most fear of newcomers (Fig. 4). Strong concerns were declared by $23 \%$ of respondents who owned farms larger than 10 ha.

Impediments encountered by farmers due to the increase of built-up areas were divided into two groups:
- infrastructural: difficult access to fields (new fences); construction sites on, so far, unused plots; narrow public roads; obstruction of so called private access roads; construction of residential buildings within a short distance of livestock buildings and agricultural buildings (inter alia manure storage facilities, silage silos);

- social: newcomers' reaction to the smell of livestock buildings, manure storage facilities, silage silos, manure that has been removed, and slurry; reaction to the noise of agricultural machines, field works after 10 p.m., road pollution, and the use of chemicals on fields (Pawlak 2011).

Sense of being "better-worse"

The other question designed to evaluate attitudes toward newcomers was: Did you ever feel that the new inhabitants consider themselves "better" than others? (Fig. 5). Results show that direct contact with newcomers seemed to arouse certain fears. A positive answer was given by $26 \%$ of respondents, regardless of the fact that only $14 \%$ answered that they have concerns about newcomers from the city. The largest proportion of respondents that shared negative feelings were found in Gdow, 41\%; and Mogilany, almost 34\%; whereas the lowest were in Brzeznica, 16.5\%; Igolomia-Wawrzenczyce, 16.9\%; and Suloszowa, nearly $20.6 \%$. 


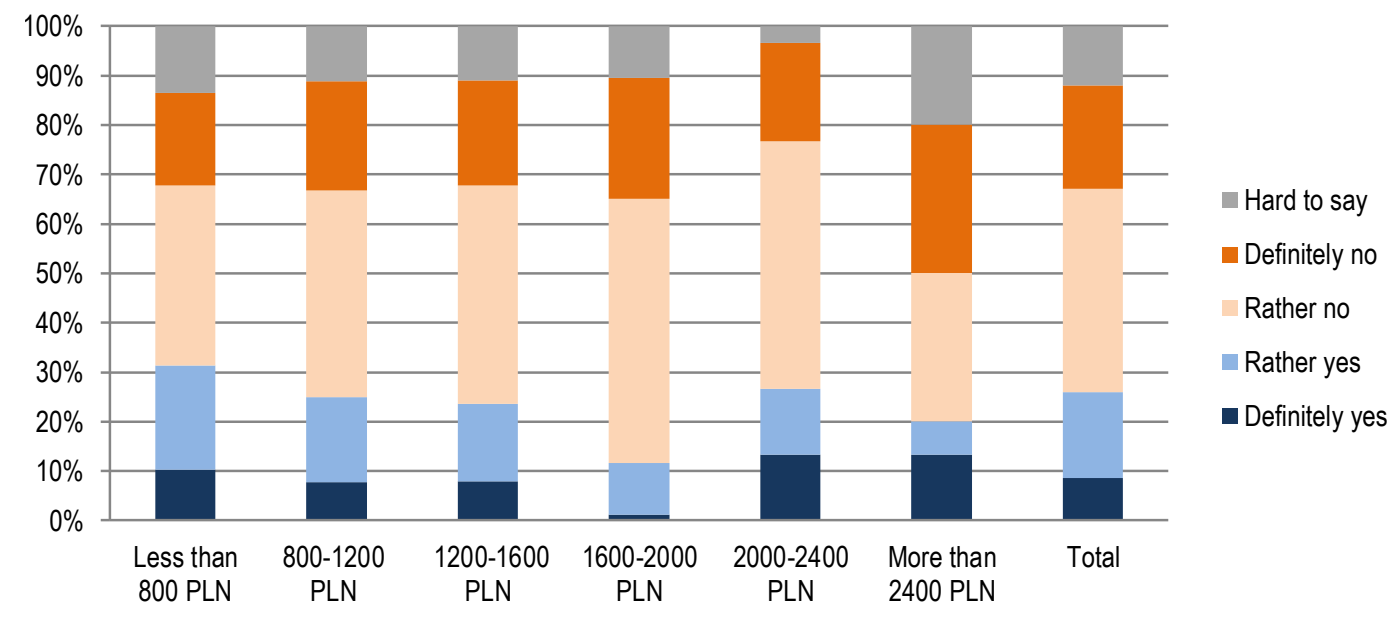

Figure 6. Respondents' sense that new inhabitants consider themselves better than the others, broken down by the level of income Source: own research

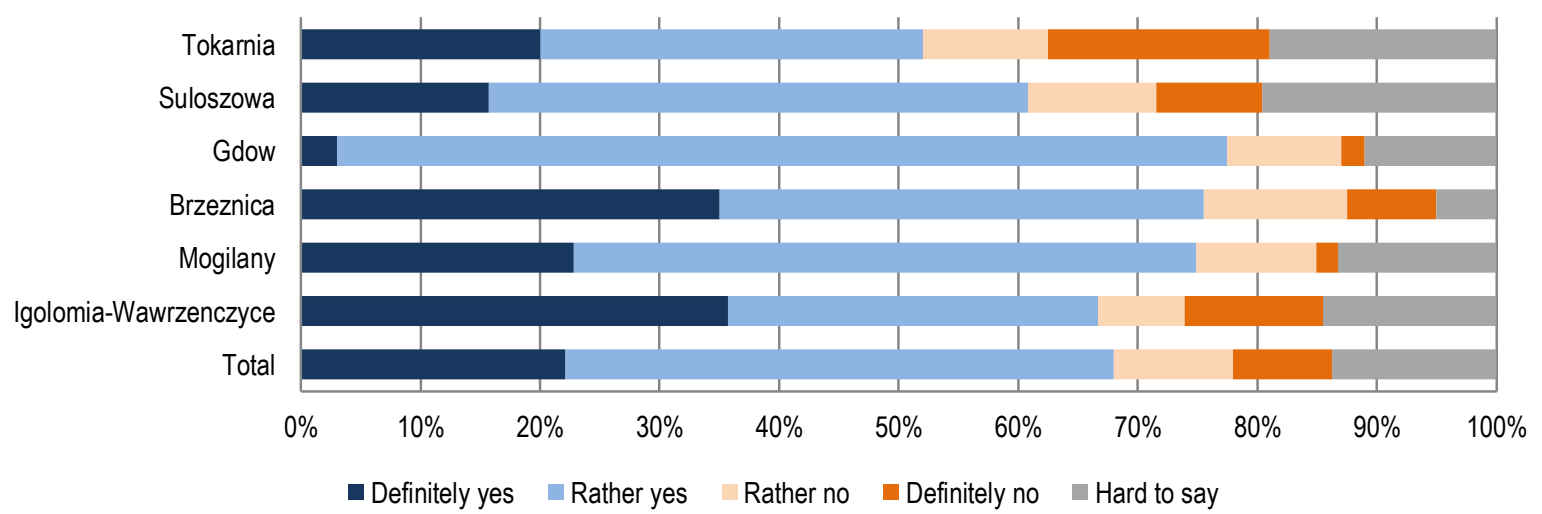

Figure 7. Consent to the sale of a building plot to a person coming from the city Source: own research

Respondents from the Mogilany and Gdow municipalities, who have experienced the highest net migration during the last 10 years, were most exposed to contact with new inhabitants (see Table 1). This frequency of contact with new neighbours, as well as certain assumptions, may shape prejudices and fears. In contrast, little contact with newcomers from the city resulted in less defined answers among respondents from IgolomiaWawrzenczyce and Suloszowa.

Taking into account another variable - income - sheds new light on the analysis of the answers to the above question (Fig. 6). The largest proportion of respondents who felt that newcomers consider themselves better, were those who declared the lowest income per capita in a household - below PLN 800 per month. Inhabitants earning PLN 1600-2400 per capita in a household were the least concerned about newcomers.

The diversity of answers due to income may be explained by the stereotype, which is well rooted among villages, of associating an urban origin with higher social status. Low income, contributing to low self-esteem, may even intensify this stereotype.

Readiness to transfer ownership of land to newcomers from the city

A strong attachment to land, often called patrimony, is observed in rural areas. The inhabitants of villages, particularly those in southern Poland, used to treat land as their sole source of food production, they were reluctant to part with it and rather tended to pass it down from generation to generation. Therefore, an attempt was made to investigate the attitudes of indigenous inhabitants toward newcomers from the city. An indirect question was asked: Would you mind selling your building plot to a person coming from the city? The answer to such a question may also indicate acceptance (or its lack) of having an immigrant from the city as a neighbour (Fig. 7).

More than $18 \%$ of respondents declared that they would not sell their building plot to a person from the city. This proportion was larger than for the question on fear of immigrants, where $14.3 \%$ of respondents answered that they were afraid of newcomers. Likewise, the proportion of undeclared respondents was higher, $13.7 \%$, versus almost $8 \%$ for those who had no opinion on concerns about immigrants. At the same time, the distribution of answers by municipality forms an interesting pattern. The largest group of respondents who declared a readiness to sell their building plots came from Gdow. Although only 3\% definitely agreed with it, it should be stressed that they were the same respondents who expressed the most of fear of newcomers from the city. Presumably, the economic factor is of a greater importance than anxiety. The opposite situation was observed 


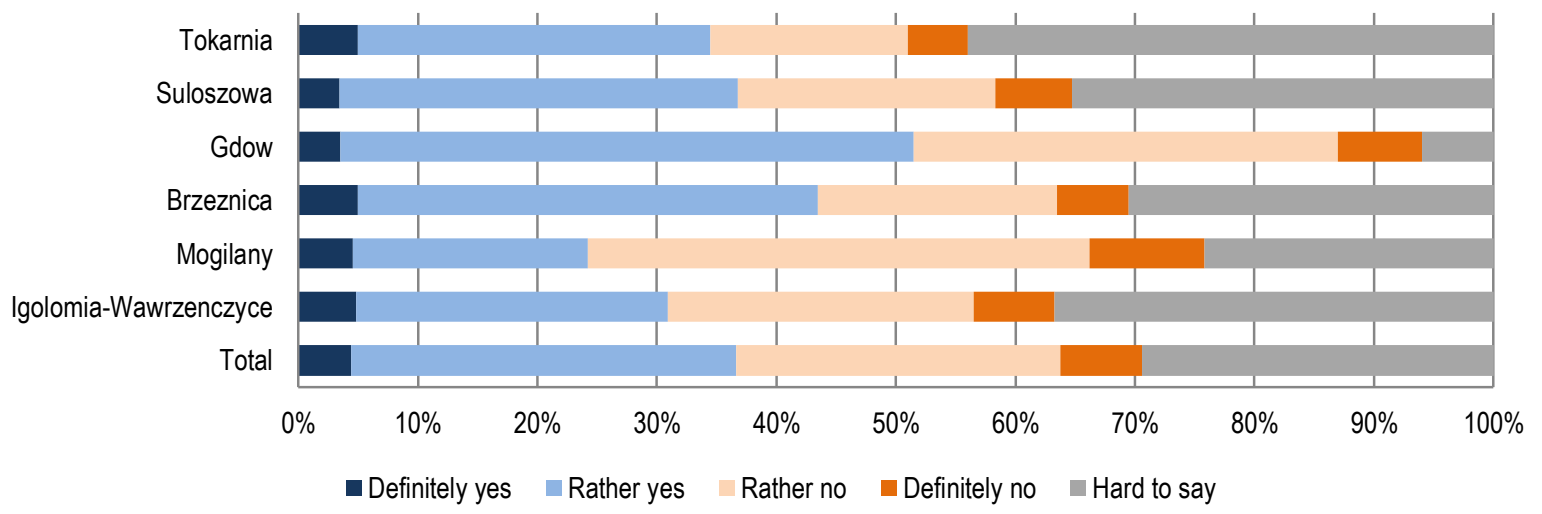

Figure 8. Newcomers' level of integration in the new place of residence, according to indigenous inhabitants Source: own research

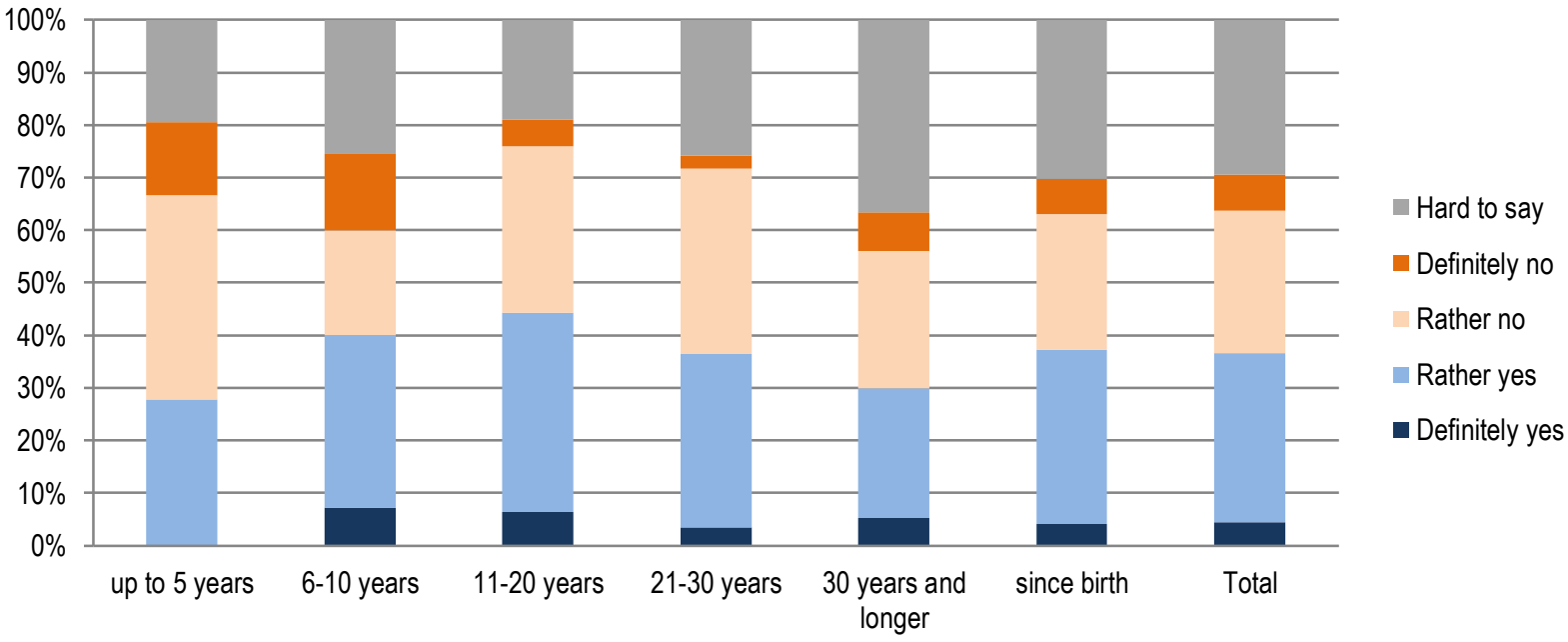

Figure 9. Newcomers' integration with a new place of residence according to indigenous inhabitants, broken down according to the respondent's length of residence in the town

Source: own research

in the Tokarnia municipality. Here up to $18.5 \%$ of respondents declared that they would not sell their building plot to a newcomer from the city (rather no, 10.5\%), whereas only $5.5 \%$ expressed strong fears toward new residents (rather yes, $9.5 \%$ ). The share of declared answers was highest in Igolomia-Wawrzenczyce almost $50 \%$. The answer "definitely yes" was dominant, $35.7 \%$, however the proportion of those who responded with "definitely no" was also significant $-11.6 \%$.

Newcomers' level of integration with a new place of residence, in the opinion of the indigenous inhabitants

Respondents assessed the level of newcomers' integration with their new place of residence. They were asked the question: Are the new inhabitants willing to integrate and identify with the village? (Fig. 8). Inhabitants of the Mogilany municipality experienced the least amount of effort by the new residents in trying to integrate; only $24 \%$ of respondents noticed such efforts. In contrast, more than half of respondents from Gdow municipality experienced a willingness by newcomers to integrate with the new place of living. Such a difference in perceptions among respondents may derive from the specific features of these two municipalities. The rural character of the
Mogilany municipality has undergone substantial transformation. For many years suburbanisation processes have been affecting the functional and spatial structure of municipality. An intensive inflow of urban population, whose needs are limited to residential functions, may intensify the sense of a lack of willingness when integrating the new and the old residents. On the other hand, the buildings in Gdow are dispersed, with new inhabitants building their houses among the existing ones, and the greater distance from Krakow forces newcomers to fulfil part of their needs in the places they are living; thus, they have more possibilities to make new contacts and integrate with the local population.

The perception of a newcomers' integration and identification with a new place of residence is also affected by how long the respondent has lived in the villages under research (Fig. 9). Respondents who had lived in a certain village for the shortest period of time declared that they had had very few experiences proving that newcomers are willing to integrate and identify with a new place. Such judgements of newcomers may result from the respondents' own behaviours and distrust about integrating at the beginning of their own lives in the village. Due to their personal experiences they might be more critical of other new inhabitants, including those coming from the city. 


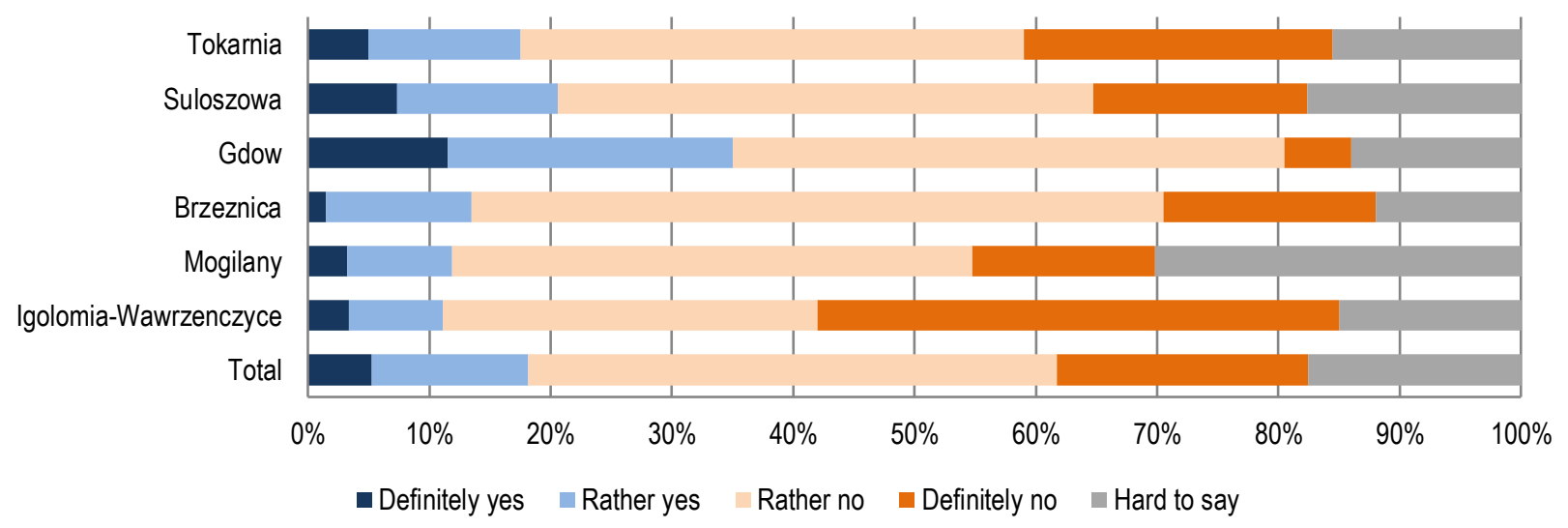

Figure 10. Opinions on the impact of newcomers from urban areas on regional tradition and culture Source: own research

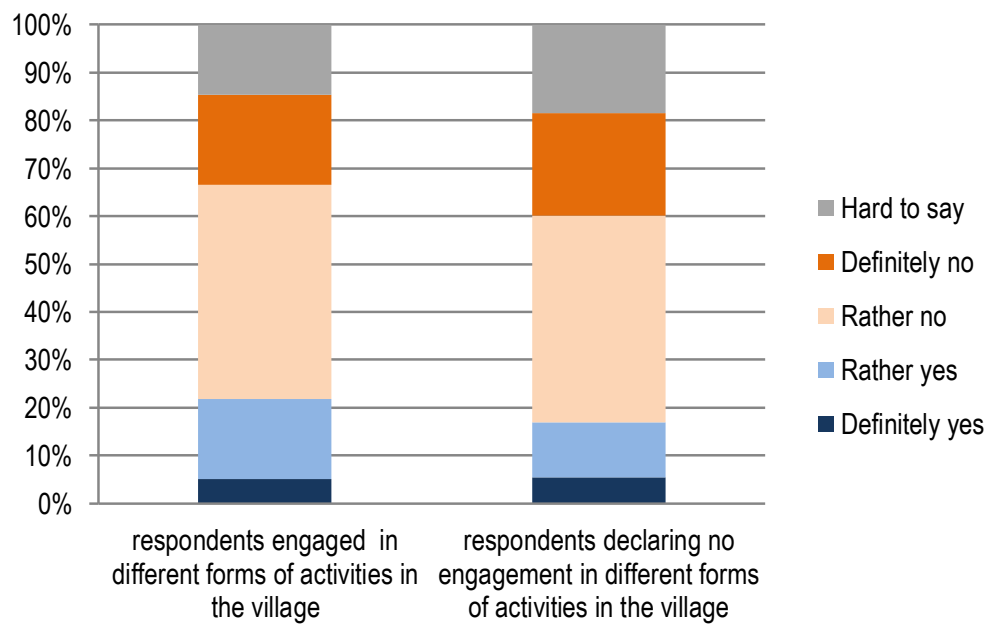

Figure 11. Opinions on the impact of urban newcomers on regional tradition and culture, broken down according to respondents' engagement in social activities

Source: own research

Assessment of urban norms' influence on the maintenance of regional tradition and culture

The inhabitants of the researched municipalities assessed if there was a dependency between the inflow of newcomers from the city and the disappearance of regional culture and tradition. A positive answer to the question, Will the inflow of people coming from outside the village cause the disappearance of regional culture and tradition?, was given by $18 \%$ of respondents, out of whom $5 \%$ definitely agreed with such an opinion (Fig. 10). However, significant differences occured between municipalities. In Gdow a positive answer was given by one-third of respondents (definitely yes was more than 11\%). Despite the fact that a substantial proportion of inhabitants from this municipality shared the view that the newcomers were eager to integrate and identify with the village, they see no influence of this in the maintaining of regional culture and tradition. The smallest number of respondents who recognised a relationship between the inflow of urban population and disappearance of tradition and culture came from Igolomia-Wawrzenczyce, Mogilany, and Brzeznica municipalities. Respondents with unspecified views comprised the largest group in Mogilany municipality (30\%).
The perception of the strength of urban norms that are being brought by newcomers from the city was compared with indigeneous inhabitants' engagement in different types of social activities (Fig. 11).

Only a slight difference is visible between the opinions of inhabitants who are socially engaged and those who are not engaged. Undecided answers were recorded more frequently among inhabitants who do not engage in the social life of a village, $18.5 \%$, versus more than $14 \%$ for those socially engaged. The latter group was clearer about the dependency between the inflow of newcomers from the city and the disappearance of tradition - nearly $22 \%$ versus $17 \%$ among those not socially engaged.

\section{Conclusions}

The development of suburbanisation in rural areas located within the city's influence zone intensified certain processes: changes in the function of rural areas, a decrease in agricultural activity, an increase in non-agricultural activities, as well as an inflow of urban population. Such important changes may lead to the interaction of distinct lifestyles, as well as to a diversification 
of the behaviours, cultures, and expectations of indigenous inhabitants and newcomers.

The study results showed the complexity of factors influencing the attitudes of the rural population toward both actual and potential newcomers. No unequivocal relationship between the location of a municipality in relation to Krakow and the attitudes of respondents was found. Distance to Krakow was only one of the factors differentiating the results. The configuration of responses was determined by, inter alia, the functional conditions of municipality, the stage of suburbanization, as well as demographic factors.

A significant group of respondents did not express any concerns about newcomers from urban areas. However, when asked about their experience with direct contact, they mentioned more often that the new residents consider themselves to be better. Owners of large farms (more than 10 ha) were among inhabitants who had many negative experiences. In fact, due to the scale of their activities they were more often exposed to contact with new neighbours. The responses were also differentiated due to the respondents' income. Respondents with the lowest income constituted the largest group of those who felt that the newcomers considered themselves better than others.

Indigenous inhabitants noticed the willingness among newcomers from the city to integrate and identify with a new place of living. However, a strong spatial diversity for answers concerning such behaviours was observed. Inhabitants who had been living in a certain village for less than five years were more critical about newcomers' attitudes toward integration. Nevertheless, in spite of noticing the newcomers' willingness to integrate, a portion of respondents, particularly those engaged in the life of a village, stated that such attitudes will not slow down the process of the vanishing tradition and culture of the region.

\section{References}

Hirt, SA 2007, 'Suburbanizing Sofia: Characteristics of postsocialist peri-urban change', Urban Geography, vol. 28(8), pp. 755-780.

Leśniak-Moczuk, K \& Moczuk, E 2002, Postawy socjologii $i$ psychologii społecznej [Fundamentals of sociology and social psychology], Wydawnictwo WSAiZ, Przemyśl Rzeszów.

Mądrzycki ,T 1977, Psychologiczne prawidłowości kształtowania się postaw [Psychological correctness of shaping attitudes], PWN, Warszawa.

Mika, S 1984, Psychologia społeczna [Social psychology], PWN, Warszawa.

Mantey, D 2011, Żywiołowość lokalizacji osiedli mieszkaniowych na terenach wiejskich obszaru metropolitalnego Warszawy [The spontaneity of the location of housing estates in rural areas of Warsaw metropolitan area], Uniwersytet Warszawski Wydział Geografii i Studiów Regionalnych, Warszawa.

Nowak, S (ed.) 1973, Teorie postaw [Theories of attitudes], PWN, Warszawa.

Novák, J \& Sýkora, L 2007, 'A city in motion: time-space activity and mobility patterns of suburban inhabitants and the structuration of the spatial organization of the Prague metropolitan area', Geografiska Annaler, Series B, Human Geography, vol. 89, (2), pp. 147-168.
Pawlak, H 2011, 'Ludność miejscowa a imigranci z wielkiego miasta' [The local population and immigrants from the big city], Studia Miejskie, vol. 9, pp. 51-60.

Špačková, P \& Ourednícek, M 2012, 'Spinning the web: New social contacts of Prague's suburbanites', Cities, vol. 29(5), pp. 341-349.

Thomas, WI \& Znaniecki, F 1918-1920, Polish Peasant in Europe and America, vol. I, Boston.

Turowski, J 1996, 'Pojęcie postawy' [The concept of attitude] in Elementy socjologii [Elements of sociology], eds $\mathrm{M}$ Bocheńska-Seweryn \& K Kluzowa, Warszawa, pp. 99-106.

Zborowski, A, Chaberko, T, Grad, N \& Kretowicz, P 2010, Delimitacja Krakowskiego Obszaru Metropolitalnego [Delimitation of the Krakow Metropolitan Area], Małopolskie Obserwatorium Polityki Rozwoju, Urząd Marszałkowski Województwa Małopolskiego, Kraków, pp. 517-543. 